SULUH

JURNAL BIMBINGAN DAN KONSELING

http://journal.umpalangkaraya.ac.id/index.php/suluh Volume 3 Nomor 1, Agustus 2017 (33-41)

\title{
PELAKSANAAN BIMBINGAN KELOIMPOK UNTUK MENUMBUHKAN SOLIDARITAS DI KELAS VIII-A SIMP GUPPI PALANGKA RAYA
}

\section{Implementation Of Group Guidance To Grow Solidarity In Class VIII-A Guppi Palangka Raya Middle School}

\author{
'Ocky Dewi Susanti, ${ }^{2}$ Andi Riswandi BP
}

Universitas Muhammadiyah Palangkaraya, Jekan Raya, Palangka Raya, Kalimantan Tengah, Indonesia

2 Universitas Muhammadiyah Palangkaraya, Jekan Raya, Palangka Raya, Kalimantan Tengah, Indonesia

\section{ARTIKEL INFO}

\section{Diterima}

Juni 2017

Dipublikasi

Agustus 2017

*E-mail:

andicronaldo@gmail.com

\section{ABSTRAK}

Tujuan dari penelitian ini adalah untuk mengetahui bentuk solidaritas peserta didik di kelas VIII-A dan Pelaksanaan Bimbingan Kelompok Dalam Menumbuhkan Solidaritas Di Kelas VIII-A SMP GUPPI Palangka Raya.Pendekatan yang dipakai dalam penelitian ini adalah dengan menggunakan metode kualitatif, Sedangkan instrument data yang digunakan adalah observasi, wawancara, dan dokumentasi. Objek dalam penelitian ini adalah guru BK, Kepala Sekolah, Wakil Kepala Sekolah Bidang Kesiswaan dan Peserta didik.Analisis data yang digunakan dengan menggunakan studi kasus. Hasil penelitian menunjukan bahwa layanan bimbingan kelompok telah berjalan dan dilakukan di sekolah SMP GUPPI Palangka Raya dan layanan bimbingan kelompok dapat dijadikan wadah bagi peserta didik dalam mendekatkan dan menumbuhkan rasa solidaritas di kelas VIII-A, karena melalui bimbingan kelompok siswa dapat mengatasi permasalahan solidaritas dan mewujudkan solidaritas tersebut dengan menanamkan rasa empati, rasa kebersamaan, kerja sama, saling menghargai dan toleransi pada diri peserta didik. Sehingga peserta didik dapat mengaplikasikan nilai-nilai dari solidaritas tersebut dalam kehidupannya sehari-hari baik dalam bersosialisasi di lingkungan sekolah ataupun bersosialisasi di lingkungan kehidupannya sehari-hari.

Kata kunci: bimbingan kelompok, solidaritas

\section{ABSTRACT}

The purpose of this study was to find out the form of solidarity of students in class VIII-A and Implementation of Group Guidance in Growing Solidarity in Class VIII-A GUPPI Middle School Palangka Raya. The approach used in this study was to use qualitative methods, while data instruments were used are observation, interviews, and documentation. The objects in this study are BK teachers, Principals, Deputy Principals for Student and Student Fields. Analysis of the data used by using case studies. The results showed that group guidance services had been carried out and carried out in the GUPPI Palangka Raya Middle School and group guidance services could be used as a forum for students to get closer and foster a sense of solidarity in class VIII-A, because through group guidance students could overcome the problem of solidarity and realize this solidarity by instilling a sense of empathy, a sense of togetherness, cooperation, mutual respect and tolerance for students. So that students can apply the values of solidarity in their daily lives both in socializing in the school environment or socializing in their daily living environment.

Keywords: group guidance, solidarity 
Jurnal Bimbingan dan Konseling

\section{PENDAHULUAN}

Solidaritas adalah rasa kebersamaan, rasa kesatuan kepentingan, rasa simpati, sebagai salah satu anggota dari kelas yang sama atau bisa diartikan perasaan atau ungkapan dalam sebuah kelompok yang dibentuk oleh kepentingan bersama. Menurut Kamus Besar Bahasa Indonesia, (2010: 552)

Agar tercapainya tujuan tersebut,maka setiap individu atau kelompok yang mendapatkan layanan bimbingan dan konseling hendaknya mempergunakan kemampuannya untuk kepentingan pribadi dan kepentingan umum dalam kehidupan bersama.

Dalam hal ini dapat dikatakan bahwa konselor juga memiliki peranan penting dalam memberikan pendidikan yang bermutu bagi peserta didik. Konselor memiliki peranan penting dalam membantu manusia agar mampu memenuhi kebutuhan belajar dan memberdayakan manusia memperoleh keseimbangan hidup melalui pendidikan yang bermutu.

Salah satu caranya menumbuhkan rasa solidaritas dapat menggunakan bimbingan kelompok. Layanan bimbingan kelompok diharapkan tepat dalam memberikan kontribusi terhadap peningkatan penyesuaian diri siswa, karena dalam pelaksanaan bimbingan kelompok, anggota kelompok akan bersama-sama menciptakan dinamika kelompok yang dapat dijadikan tempat untuk mengembangkan penyesuaian diri. Disamping itu, anggota kelompok mempunyai hak yang sama untuk melatih diri dalam mengemukakan pendapatnya, membahas masalah penyesuaian diri dengan tuntas, dapat saling tukar pengalaman dan informasi, dan memberikan saran kepada anggota lain. Menurut Rusmana (2009: 13)

Bimbingan kelompok dapat didefinisikan sebagai suatu proses pemberian bantuan kepada individu melalui suasana kelompok yang memungkinkan setiap anggota untuk belajar berpartisipasi aktif dan berbagi pengalaman dalam upaya pengembangan wawasan, sikap atau keterampilan yang diperlukan dalam upaya mencegah timbulnya masalah atau dalam upaya pengembangan pribadi.

\section{METODOLOGI PENELITIAN}

Pemilihan pendekatan kualitatif dalam penelitian ini didasari atas keadaan yang sebenarnya pada objek tertentu serta berusaha untuk menemukan serta memaknai setiap gejala yang dilakukan oleh setiap subjek penelitian sesuai dengan permasalahan penelitian. Pendekatan Kualitatif menurut Sugiyono (2013:15) menyatakan bahwa: "Pendekatan kualitatif adalah pendekatan penelitian yang digunakan untuk meneliti pada kondisi objek alamiah (sebagai lawannya adalah eksperimen) dimana peneliti adalah sebagai instrument kunci. Teknik pengumpulan dengan triangulasi (gabungan), analisis dan bersifat induktif, dan hasil penelitian kualitatif lebih menekankan makna daripada generalisasi”.

Menurut Sugiyono (2013: 506) "Titik tolak pengumpulan data dengan metode kualitatif adalah data yang terkumpul pada penelitian tahap pertama dengan metode kuantitatif". Data tersebut selanjutnya dibuktikan kembali, diperdalam, diperkuat, dan diperluas dengan data kualitatif. Untuk memperoleh data kualitatif yang kredibel, maka digunakan metode kualitatif. Sampel sumber data dalam penelitian kualitatif bersifat purposive sampling artinya sumber data tersebut dipilih berdasarkan pertimbangan tertentu atau tujuan tertentu

\section{HASIL DAN PEMBAHASAN}

Pelaksanaan Bimbingan Kelompok Dalam Menumbuhkan Solidaritas di Kelas VIII-A Bimbingan kelompok telah dilakukan di sekolah SMP GUPPI Palangka Raya dalam upaya menumbuhkan solidaritas peserta didik 
Jurnal Bimbingan dan Konseling

dalam sosialisasinya, sekolah sebagai tempat berlangsungnya proses belajar mengajar juga sosialisasi peserta didik baik karena pihak sekolah SMP GUPPI telah menanamkan dan memberi pengarahan semenjak mereka awal masuk SMP GUPPI yaitu saat mereka kelas VII. Langkah-langkah yang dilakukan sekolah terhadap peserta didik demi menumbuhkan rasa solidaritas diantaranya adalah dengan memberikan layanan bimbingan kelompok dengan adanya bimbingan kelompok peserta didik kepada peserta didik dalam menempatkan diri pada lingkungan sosialnya baik lingkungan sosial sekolah ataupun lingkungan sosial sehari-hari. Layanan bimbingan kelompok peserta didik bisa saling mengungkapkan masalahnya, saling sharing dan bersama-sama mencari solusi dari masalah yang dihadapi anggota kelompoknya dengan menghidupkan dinamika kelompok. $\mathrm{Hal}$ ini sesuai dengan tujuan bimbingan kelompok yang memberi kesempatan anggotanya untuk belajar mengutarakan permasalahannya dan pendapatnya terkait tentang sosialisasi dan pemahaman dirinya. Bimbingan kelompok pada dasarnya dapat mencegah dan memperbaiki bidang - bidang pribadi, sosial, belajar Menurut Rusmana (2009: 13) Bimbingan kelompok dapat didefinisikan sebagai suatu proses pemberian bantuan kepada individu melalui suasana kelompok yang memungkinkan setiap anggota untuk belajar berpartisipasi aktif dan berbagi pengalaman dalam upaya pengembangan wawasan, sikap atau keterampilan yang diperlukan dalam upaya mencegah timbulnya masalah atau dalam upaya pengembangan pribadi.

Pemberian layanan bimbingan kelompok diharapkan tepat dalam memberikan kontribusi dalam menumbuhkan sikap solidaritas peserta didik dalam menghadapi permasalah dalam sosialisasi pertemanan anak usia remaja khususnya solidaritas di kelas VIII-A SMP GUPPI
Palangka Raya. Pelaksanaan layanan bimbingan kelompok anggota kelompok bersama-sama adalah bertujuan untuk: Menciptakan dinamika kelompok yang dapat dijadikan wadah pengembangan diri peserta didik misalkan dengan melakukan permainan sederhana yang akan memancing keakraban dan komunikasi juga minat peserta didik terhadap bimbingan kelompok. Melatih peserta didik mengemukakan pendapatnya dengan bimbingan kelompok peserta didik dilatih untuk mengemukakan pendapat serta bertukar pemikiran. Membahas permasalahannya, dengan bimbingan kelompok peserta didik dibawa untuk membahas dan memecahkan masalah bersama. Bimbingan kelompok wadah atau tempat bertukar pengalaman dan informasi sehingga bisa saling memberi saran kepada anggota kelompoknya. Guru BK juga bekerja sama dengan guru bidang studi, wakil kepala sekolah bagian kesiswaan yang juga berperan aktif dalam menumbuhkan sikap solidaritas peserta didik. Masalah solidaritas yang terjadi disekolah adalah suatu bentuk masalah yang harus dihadapi dan ditanggulangi bersama oleh semua pihak sekolah baik itu guru mapel dan guru BK di sekolah ataupun Wakil Kepala Sekolah Bidang Kesiswaan.

Solidaritas peserta didik di kelas VIII-A Ada peserta didik yang mengalami kurang memiliki rasa solidaritas yang baik hal ini terlihat dalam sikap kurangnya kepercayaan, masih adanya membeda-bedakan orang dalam pergaulan, masih enggan menyumbang untuk kepentingan bersama, mencari-cari kesalahan orang lain, kurang berempati terhadap masalah yang dialami temannya.

Durkheim (dalam Sukodoyo dkk : 66) menyatakan bahwa : Solidaritas merupakan suatu keadaan hubungan antara individu dan atau kelompok yang didasarkan pada perasaan moral dan kepercayaan yang dianut bersama dan diperkuat oleh pengalaman emosional bersama. Solidaritas menekankan 
pada keadaan hubungan antar individu dan kelompok dan mendasari keterikatan bersama dalam kehidupan dengan didukung nilai-nilai moral dan kepercayaan yang hidup dalam masyarakat. Wujud nyata dari hubungan bersama akan melahirkan pengalaman emosional, sehingga memperkuat hubungan antar mereka.

Hal ini disebabkan oleh masih adanya pola pertemanan yang berkubu-kubu sehingga sebagian peserta didik belum bisa mewujudkan arti dari solidaritas yang sebenarnya dalam lingkungan sekolah SMP GUPPI khususnya kelas VIII-A.

Namun pihak sekolah SMP GUPPI baik wali kelas, guru BK, wakil kepala sekolah bidang kesiswaan, ataupun Kepala Sekolah SMP GUPPI Palangka Raya selalu mengawasi, menghimbau, memberi arahan dan memberi nasehat agar tetap terwujudnya ketenangan, kenyamanan, keakraban dan kekeluargaan di lingkungan SMP GUPPI Palangka Raya.

\section{KESIMPULAN}

Solidaritas yang terjalin di SMP GUPPI khususnya Kelas VIII-A baik karena pihak sekolah SMP GUPPI telah menanamkan dan memberi pengarahan semenjak mereka awal masuk SMP GUPPI yaitu saat mereka kelas VII bahwa kita itu sesama teman dalam satu kelas, satu sekolah, satu Yayasan adalah satu saudara. Namun terkadang masih terdapat perselihanan dalam pergaulannya hal ini dikarenakan pola pertemanan mereka yang masih berkelompok dan membangun kubukubu, namun selama ini hal tersebut masih bisa dikendalikan oleh guru BK.

Layanan bimbingan kelompok sudah dilakukan di SMP GUPPI Palangka Raya hanya saja dalam pelaksanannya peserta didik masih kurang variatifsehingga peserta didik kurang antusias atau aktif dalam pelaksanaan layanan bimbingan kelompok. Guru BK mewujudkan solidaritas tersebut dengan menanamkan rasa empati, rasa kebersamaan, kerja sama, saling menghargai dan toleransi pada diri peserta didik. Sehingga peserta didik dapat mengaplikasikan nilai-nilai dari solidaritas tersebut dalam kehidupannya sehari-hari baik dalam bersosialisasi di lingkungan sekolah ataupun bersosialisasi di lingkungan kehidupannya sehari-hari

\section{DAFTAR PUSTAKA}

Bahasa, Pusat. 2008. Kamus Besar Bahasa Indonesia. Jakarta. Gramedia Pustaka Utama

Rusman, Nandang. 2009. Bimbingan Dan Konseling Kelompok Di Sekolah. Bandung. Rizqi Press

Sugiono. 2013. Metode Penelitian Pendidikan (Pendekatan Kuantitatif, Kualitatuf, dan $R \& D)$. Bandung: Alfabeta

Sukodoyo. 2015. Hubungan Self Efficacy Dan Solidaritas Kelompok Terhadap MinatPemuda Buddhis Dalam Mengikuti Kegiatan Keagamaan. ISSN: 2460-I I 44 